\title{
Pedagogical values of Renaissance travels
}

\author{
Agnieszka Katarzyna Gębora* \\ Higher School of Wholesome Education and Social Sciences 21 Kamińskiego St., 90-229 Łódź, \\ Poland \\ *E-mail address: k.gebora@wp.pl
}

\begin{abstract}
The time of the Renaissance created the new model of the man-humanist. European patterns stimulated to the cultural or educational development of different fields of the social life. A bloom of the education took place, a thirst for knowledge, an interest in learning, world, travels, getting new experiences. A man educated, being good at foreign languages, opened for changes was appreciated. Geographical discoveries and their effects forever changed the image of the earth. Sixteenth-century peregrinations contributed to the development of states, economic and civilization expansion, and the bloom of culture area.

Pedagogic meaning of Renaissance journeys is indisputable. Experience from voyages all over world, extending ranges, the permeation of cultures, the learning of foreign languages, the increase in the knowledge, the development of learning, education and artistic fields bear fruit to this day in the global scale.
\end{abstract}

Keywords: voyage; motives; educational aspect; profits; the Renaissance

\section{INTRODUCTION}

In order to make an attempt of the evaluation of sixteenth-century peregrinations in the aspect of their pedagogic values, historical preliminary research of all available source materials were necessary. The analysis of facts and situations found in travel materials which became for authors of written diaries, daily newspapers, story, chronicles, letters, documentaries, diaries, reports the factors transforming their personality, a system of values, the aspect of the tolerance, the ratio to other cultures and nations, the ways of thinking about other people. Because travel experience has a special influence on practical attitudes of travelers causes fundamental ideological transformations. Considering the taken subject matter and the temporary censorship discussed issues were analyzed from theoretical, pedagogic and historical point of view.

Travels are one of the oldest examples of the human activity. Already in ancient times the population migrated beyond the area of the own domicile. However the first transfers had not only character of the territorial expansion (crusades, wars), whether of diplomatic departures or commercial expeditions, but they were also dictated with individual needs, i.e.: religion, health, pleasure. Already in these distant times curiosity about world, need of spiritual and cognitive experiences made people travel.

Travel (from the Latin called the peregrination, from French - journey), it is a change of address on distant one, it covers the road to some remote place. W. Kopaliński claims that 
former attribute "peregrination", spelt a long journey, the walk, the tramp or the pilgrimage. Etymological explaining the word "peregrination" is : Lat. Peregrinatio - "travel" (stay abroad; "pilgrimage" from peregrinus - foreigner; "pilgrim" from peregre "abroad". (Kopaliński, 2005)

Travelling man from those times- peregrinatio is a contemporary equivalent -traveler. It is the man consciously making an effort to travel, still moving in order to get to know the beauty of the world who is interested in peculiarities of world, its natures, cultures, architectures. He also makes lives in order to shape the world view, system of values or philosophy. Humans travelled to distant countries because of economic and political reasons but also cognitive, that is typically touristic. (Turos, 1990)

In the literature on the subject a lot benefits from travelling occurred. The travel brings latest experiences, can symbolize the willingness of cognitions, escape, seeking happiness or better living conditions, can finally join with mission, passion. The travel has also educational advantages, it teaches something new, verifies previous experiences, provokes reflection and auto reflection, deepens the dimension of the individual humanity. Educational travelling teaches about the diversities of the human existence, gives chances of getting to know other cultures and lifestyles. From here the saying "travel broadens the mind".

Journeys affect the broad development of the man, constitute the source of knowledge. They strengthen the meaning of life feeling, activate, stimulate creatively and intellectually. They widen the prospect of seeing the world, integrate socially, experience educationally. They offer the wealth of experiences: aesthetic, artistic, spiritual and relaxation. (Dzięgielewska, 2001)

To the 15th century residents of Europe have rarely sailed out beyond the swimming area of the Mediterranean sea, confined themselves to the inshore navigation on the Atlantic Ocean. $15^{\text {th }}$ and the $16^{\text {th }}$ century are times, when voyages of discovery directed the remark of Europeans towards new continents and for their residents. Travels and their effects connected with them directly in the form of geographical discoveries were a turning point in the history of Europe and the world.

The Renaissance was an century opening modern times. The difference between "old" and "new" European culture was large, since on the XV/XVI turn of the century in Italy, and in the 16th century in other parts of the continent, the thinking of the man changed entirely, his approach towards the art and the philosophical and literary tradition.

The Renaissance is the time of great individuals. Everyone who felt in oneself rising tide of talent, unwound it thoroughly. The man was not well up to one discipline, very often performed a lot of functions: professional, social, political, artistic. The Renaissance gave rise to many geniuses whose achievements until today arouse the respect and the admiration, because of finding practical application.

The new age emphasized the extraordinary dignity of every man, values of the earthly life. Curiosity about the world and desire for discovering it were connected with a value of world life understood here and now. This was a gigantic field, which should be discovered and examined. That is why 15th and the 16th century is a time of great geographical discoveries and study tours. The Renaissance is also a period of the learning. A press appeared which incited the entire age to rebellion, thinking about the world and the communication. Books which until then were almost inaccessible and unattainable because of their price, became the common good. This event affected the speed of the transmission of the idea and thoughts. It is not possible to forget that the Renaissance is a time, in which people used ancient achievements which were treated as a model. 
Having such a historical background of the age lots of people decided to go on a tour. As we think about the travel no matter how it is defined, a motive and a purpose and functions which it fulfills are significant especially if they have influence on the participant of the expedition. It is possible to perceive the travel as an educational situation, shaping knowledge, stimulating auto education, influencing emotions and being a latest experience. The dimension of the word 'travel' has a philosophical-metaphorical character which perfectly fits to a Renaissance man. It is a transgressional man, seeking, opened, heading to numerous lands and values and purposes. Ontic aspect of travel is expressed through its fundamental subject, i.e. the travelling man. Travels can be the way the man existing, way of carrying different values, way of getting to know world, his predictions, being with others; finally they can be a realization of freedom.

The Renaissance carried certain long-lasting values into the general culture, e.g. avocation for seeking something new, unknown, particularly important for the man. The need of cognition, an aesthetic experiences, the diversity of experience were also crucial. People decided to give up the one-way medieval contemplation of the spiritual life, refreshing the sensitivity in the process and restoring the faith in the sense of existence.

It should be emphasized that before journeys were very rare, in comparison to contemporary tourist movements, most often available to a narrow and wealthy social group. There were various purposes of journeys: educational, religious, commercial, diplomatic, for pleasure etc. For the development of the public culture they had crucial meaning, formed prototypes and models of travelling. Getting to know world was one of essential motives for them.

Representatives of the Renaissance in their statements showed a special system of values. They felt responsible for fates of their own country. They treated travels as perfect opportunity to seeing other nations, seeking valuable social solutions, adopting customs, laws and useful methods strengthening the economy, the country's defense and raising the culture. They talked not only about utilitarian aims of travels. Travels were supposed to be a school of the civil upbringing, the source of the social and political conventional wisdom.

Travelers gained knowledge from guidebooks which pointed interesting places, tourist and commercial paths. They contained also advice connected with the quality of roads and accommodation places. River, sea and land transport played an important role. The increased rush of passengers supported the development of cities, settlements and ports. A lot of initiatives of transports were taken.

The Renaissance period brought discovering America by Christopher Columbus, opening the sea route to India by Vasco da Gama, sailing around the globe by Ferdinand Magellan. As a result of above achievements it reached the next development of the travel. (Favenc, 2006)

In the period of Great Discoveries considerable the four-times extension of spatial horizons took place, as well as the change of existing ideas about numbers, sizes, arranging lands and oceans on the globe, dimensions of the Earth. (Staszewski, 1963)

For the first time in history the civilization of the 16th century gained knowledge about all inhabited continents what was a beginning of irreversible historical changes.

Following these discoveries, a development of cartography took place. An image of the Earth described on new maps underwent the turnabout. In maps collection of Ortelius and Merkator published in the 16th century in Flandria, maps of Ptolemy, on which earlier they were based, were completely omitted. In cartographic field giving a conformal map of the world of earlier recalled Gerard Merkator was a coup. 
Discovering America brought up the big amount of new geographical discoveries. An era of expeditions, being a multidimensional and timeless phenomenon came. In 15 th and the 16th century a conviction about the evangelizing mission existed in Europe. Especially expeditions of the Portuguese and Spaniards attest to it. In more late centuries the overseas expansion was an effect of the extension oneself of geographical ranges. Also a knowledge spread about the spherical shape of the Earth.

In 15th and 16th century a conviction about the evangelizing mission existed in Europe. Especially expeditions of Portuguese and Spaniards confirm it. In more late centuries the overseas expansion was an effect of the extension oneself of geographical ranges. Also a knowledge about the spherical shape of the Earth spread.

Thanks to sea travels various parts of the world were got to know. International contacts were established. A fleet and ports were extended. Seaside cities with economic and cultural institutions came into existence. New markets gave in the perspective the chance of the development, widened areas of the human activity. Progress of the scientific knowledge took place. They widened the border of inhabited lands.

The 16th century was characterized by substantial changes in the European economy. A development of cities and settlements, the goods-money exchange and the farming progressed. The old fell down and new centers of the economic life were formed, a change of trade routes took place as a result of conquests and geographical discoveries. In the foreign trade Portugal and Spain were crucial, next Netherlands, France and England. Walks in search for new areas resulted in development of these states, economic and civilization expansion, development of culture areas. Thanks to commercial trips distant regions were got to know, knowledge about culturally different societies appeared. Through international contacts customs and traditions of native inhabitants were got to know. European models were moved to the discovered parts of the world. (Babicz, 1968)

Peregrinations contributed to the development of many positive social processes. Thanks to them an economic development of the town, regions and countries took place. A social mobility increased. A development process of the education took place.

Diplomatic and parliamentary missions, war expeditions, commercial travels, academic peregrinations brought profits in many fields. Standards linked to political-social, military, economic, cultural, scientific or artistic areas appeared.

In the 16th century they started forming permanent diplomatic missions at the most important political centres in Europe. The characteristic phenomenon in the time of the Renaissance was considerable enlivening the contacts, inside country as well as on the international arena. Relations occurred on many areas: cultural, diplomatic, religious, political or economic. More often than in the Middle Ages, peregrinations to different countries took place, connected with studies, tourism, cognitive, missionary, diplomatic, commercial purposes. Also pilgrimages to holy places, often connected with sightseeing were organised.

In the Renaissance peregrinations were various targets. Despite the character of the journeys all over the country, or Europe, peregrinations had a cognitive advantage. People tried to get to know various regions, residents, their lifestyle, views, language. Sociopolitical relationships, a different culture, history, achievements of the science and technology were of people's interests. Architecture and topography of cities fascinated. Different landscapes, the difference of the flora and faunas or natural phenomena were also very interesting. It is possible to find confirming cognitive interests in many relations of contemporary travelers.

(Mączak, 1994)

All over Europe the Reformation spread. Thanks to the migration of the population it penetrated into many political spheres, social, cultural, social or individual. E.g. a 
development of the writing and printings, bloom of the education, growth of an interest in the Bible, interdenominational polemics, reinforcing the national awareness, the social-economic and financial development, the increase in the level of education or the development of centres gathering outstanding intellectuals were a positive effect. The first-generation of intellectuals practised the walking missionary activity, moved right away from one place to another. It also established contact with many distant centres of the Reformation movement. The Reformation penetrated to influential circles, including the royal manor house. It propagated the development of national literature, religious and sociopolitical changes. The Reformation brought in the essential contribution to the development of the grammar and style, sciences and educations. It revived also a publishing movement.

In the 16th century the first works of the military theory in Europe started. Thanks to war expeditions and overseas expeditions a knowledge was acquired and experiencing in methods of fight, training, tactics, weaponry or fortified buildings. A development of the art of war and fortification took place. New organization systems of the army appeared. A regular system and forming the permanent royal fleet became widespread. Sailors were trained. As a result of changes in military tactics, as well as due to the influence of the literature of the antiquity, a theoretical war knowledge started coming into existence. Through the migration of armies into various regions of the Old Continent and World, standards for the modernization of the military and training army appeared. A big interest in the physical fitness of soldiers was noticeable. They started also appreciating their level of education intellectual, command of foreign languages. A patriotic and civil upbringing acquired significance. Getting to know cultures of other nations accompanied the migration of armies.

Travels became also an intellectual adventure. People learnt determined standards of surviving, thinking, social behaviour. They freed themselves of myths and stereotypes. They modernized and updated the knowledge.

Raports and diaries came into existence mainly some time on one's return from the peregrination. Unwillingly people admitted to the total change of beliefs due to the influence of the held journey. A lot of expeditions took place in order to get confirming some opinion.

From the 16th century it was possible to observe the expansion of native languages on the area of Europe although a Latin still functioned. Thanks to the migration of the population, the settlement or travelling in various purposes, a permeation of cultures, the tradition and language of other nations took place.

The Renaissance travel performed a lot of social significant functions. Thanks to contacts with other communities understanding and the tolerance for other cultures grew. Determined values were handed over to others as well as the ways of behaviors, customs or clothes, etc. A history of the given country was learnt, sociopolitical conditioning and economic, system of beliefs. They aspired to higher level of education through the learning of foreign languages or broadening their knowledge of different fields, e.g. in geography, astronomy, physics, mathematics of cartography, military science, architecture, the plastic arts, music, philology, literature, etc. (Badowski, 2007)

A level of the culture rose. Wanderers returning from the journey provided information about culture of visited countries, monuments, customs, about the works of art and beauty of the exotic nature.

Almost every travel, in spite of its character, widened the limits of its mental abilities of the society, influenced for creating the awareness of individual groups, supported for development of the education, the culture and the learning.

The 16th century was connected with transformations in the education, with spreading the book, the build-up of information and dynamics of contemporary socioeconomic 
relationships. New education concepts were noticeable already at the close of the Middle Ages, peculiarly in the Italian cities. Attempts of more rational bringing up young people were made. In the 16th century in Italy those schools achieved fame, where the upbringing was based on humanistic bases. Apart from the elementary knowledge, they put emphasis on the physical education through different forms of the activity: cognitive and artistic trips, swimming, dance, horse riding, sports classes and so on. Besides advantages of typically utilitarian, an aesthetic experience were important. Also teaching methods facilitating assimilating knowledge were introduced. In the physical education healing and preventive advantages were noticed. Both schools cleared the way for education transformations of the age of the Revival. They affected the development of the humanistic pedagogic theory. A broad development of the man became main setting the school.

Thanks to peregrinations, exchange the opinions, above pedagogic ideals spread all over, particularly western European countries. The most rapid development took place in the North in the Netherlands. Cities, thanks to trade, sea navigation became wealthy. Education matters were also taken care of. They developed the basic education in the native language, about the practical-merchant profile and Latin secondary schools for the social upper classes.

Thanks to the development of the education the meaning of the pedagogic profession grew. A printing was developed. A cultural life underwent the revival. Thanks to Italian and Dutch experience, a new course was noticeable in the French and German education. Also colleges were reformed. Universities have good contacts, both among students, as well as academic teachers. They exchanged the achievements.

The age of the Renaissance created the latest model of the man-humanist. European patterns stimulated to development of different fields: the cultural or educational or the social life. A bloom of the education took place, a thirst for knowledge, an interest in learning, world, travels, getting latest experiences. A man educated, being good at foreign languages, opened for changes was appreciated. (Ziomek, 1997)

In the 16th century, thanks to journeys of artists all over Europe, such fields of art as: literature, the painting, the sculpture, architecture or the music developed. (Barycz, 1968)

\section{CONCLUSION}

Travelling is this form of the activity which appears in all cultures and historical times. Biographies of travelers, daily newspapers, lists, diaries, memories, chronicles, press texts or literary works confirm it.

To sum up we should emphasize that pedagogic meaning of Renaissance journeys is indisputable. People should notice the vision of positive changes on the level of not only individual subjects, concentrating thanks to the travels based on the spiritual selfdevelopment, but also results of these travels in the wider dimension. Experience gained from journeys all over world, extending ranges, the permeation of cultures, the learning of foreign languages, the increase in the knowledge, the development of learning, education and artistic fields exist to this day in the global scale. 


\section{References}

[1] Babicz J. , Walczak W., Zarys historii odkryć geograficznych, PWN, Warszawa 1968,

[2] Backvis C., Dziennik podróży Polaka po Włoszech i Hiszpanii, przeł. K. Witwicka, [w:] C. Backvis, Szkice o kulturze staropolskiej, PIW, Warszawa 1975,

[3] Badowski R., Odkrywanie świata, Wyd. Pascal sp. z.o.o., Bielsko-Biała 2007.

[4] Barycz H., W blaskach epoki Odrodzenia, PIW, Warszawa 1968,

[5] Barycz H., Z dziejów polskich wędrówek naukowych za granicę, Ossolineum, Wrocław 1969 ,

[6] Białostocki J. (przekł. ), Dziennik podróży do Niderlandów [w:] Albrecht Dürer jako pisarz i teoretyk sztuki, J. Białostocki (oprac.), Ossolineum, Wrocław 1956

[7] Czubek J. (wyd.), Anonima Diariusz peregrynacji włoskiej, hiszpańskiej, portugalskiej (1595), Polska Akademia Umiejętności, Kraków 1925.

[8] Dzięgielewska M., Podróże naukowe jako forma zdobywania wiedzy [w:], O. Czerniawska, B. Juraś-Krawczyk (red.) Podróże jako projekt edukacyjny, WSHE, Łódź 2001.

[9] Köb Susanne - Filozofia podróży. Wyd. Focus Giessen, Niemcy 2005.

[10] Krawczyk Z., O turystyce i rekreacji, Studia i szkice, Wydawnictwo ALMAMER Wyż. Szkoły Ekonomicznej, Warszawa 2007.

[11] Kukulski L., Radziwiłł M. K. , Podróż do Ziemi świętej, Syrii i Egiptu 1582-1584, PIW, Warszawa 1962,

[12] Mączak A., Peregrynacje, Wojaże. Turystyka, Czytelnik, Warszawa 1984.

[13] Mączak A., Życie codzienne w podróżach po Europie w XVI i XVI wieku, PIW, Warszawa.

[14] Przecławski K., Turystyka a wychowanie, Nasza Księgarnia, Warszawa 1973.

[15] Serwański M., Wiek XVI-XVII, Wyd. Poznań 2008.

[16] Staszewski J. (red.), Historia odkryć geograficznych. Odkrywcy i badacze Ziemi, przeł. B. Wojciechowski, PWN, Warszawa 1963,

[17] Turos L. Turystyka edukacyjna, Wyd. Wyższa Szkoła Rolniczo-Pedagogiczna w Siedlcach, Siedlce 1990.

[18] Ziomek J., Renesans, PWN, Warszawa 1997. 